\title{
LA ICONOGRAFÍA DE LA VIRGEN DE GUADALUPE DE MÉXICO EN ESPAÑA
}

Actualmente se conserva en la geografía española un importante conjunto de pinturas procedentes del virreinato de la Nueva España. Las investigaciones revelan que fueron traídas durante los siglos XVII y XVIII con una función sobretodo devocional, formando parte de ajuares personales. El origen de este proceso está en la multitud de funcionarios y clérigos españoles afincados en la Nueva España. Sus destinos fueron, por tanto, domicilios particulares, iglesias y conventos de sus localidades natales.

La gran mayoría tienen por tema a la Virgen de Guadalupe. Para comprender la importancia que alcanzó esta devoción en el virreinato es preciso remontarse a sus inicios. Aunque la de Extremadura estuvo presente durante la conquista, la mexicana ostenta orígenes propios. Una antigua leyenda narra como en 1531 se le apareció a un indio recién bautizado con el nombre de Juan Diego y le pidió que le solicitara al obispo fray Juan de Zumárraga la construcción de una capilla en su honor, dejando su imagen impresa en el ayate (túnica) del indio. Este suceso se conoció como el Milagro de las rosas y fue recogido en el Nican Mopohua, un texto presuntamente escrito por el indio Antonio Valeriano. ${ }^{1}$

No tardó en surgir una literatura destinada a legitimar este portento que generó un gran incremento de su culto, especialmente entre el sector indígena. Los evangelizadores trataron de asimilarla con la diosa-madre azteca Tonantzin para aprovecharse del fervor del que esta gozaba. ${ }^{2}$ Los indios la vieron como una figura protectora con la que se sentían identificados. También los criollos la prefirieron a la extremeña y lucharon por desvincularla de esta, una actitud que puede considerarse el primer paso en el surgimiento de la conciencia nacional mexicana.

El impulso a su devoción coincidió con la buena aceptación de la que gozaba la Inmaculada Concepción y el nuevo fervor hacia las vírgenes "indias". El virreinato se llenó de devociones autóctonas que simbolizaban los valores nativos. Las imágenes eran el principal instrumento para cristianizar a los indios, y la Virgen de Guadalupe llegó a ser la más importante. El criollo Luis Becerra Tanco fue el primero en apuntar que su tez morena era una distinción hacia el pueblo indígena.

Aunque apenas tienen en común algo más que el nombre, ha habido múltiples intentos de relacionarla con su homónima de Extremadura. Según Miguel Rojas ambas son la misma, solo que allí se hizo mexicana y así regresó a su lugar de origen. ${ }^{3}$

Infinidad de anécdotas avalan el fervor guadalupano en la Nueva España. Un caso habitual fue el de fray Francisco de Frutos, quien se encomendó a ella ante una grave enfermedad, siendo salvado. En señal de agradecimiento peregrinó hasta su santuario en el Monte Tepeyac, donde hizo ejecutar al pintor Juan Correa "una réplica exacta de la imagen pintada por los ángeles con flores, mientras que él mismo se mantuvo en oración junto al artista, actitud tradicional del donante en los retablos". ${ }^{4}$ Una crónica del año 1723 señalaba que no existía casa de noble y plebeyo, español e indio y otras muchas castas en las que no hubiera alguna imagen de la Virgen de Guadalupe.

Ilustres escritores difundieron su carácter milagroso y genuinamente novohispano. El teólogo Miguel Sánchez contaba por primera vez la historia de las apariciones como un hecho profético de connotaciones nacionalistas. El Padre Luis Lasso de la Vega escribió una especie de manual

\footnotetext{
1 Ansón, Francisco. Guadalupe, lo que dicen sus ojos. Madrid, 1988, pp. 17-19.

2 Este hecho fue denunciado por fray Bernardino de Sahagún. SAHAGÚN, fray Bernardino de. Historia general de las cosas de Nueva España. Madrid, 1990 (1570). Para Jacques Lafaye los dos mitos principales de la Nueva España son Quetzalcóatl/Santo Tomás y Tonantzin/Guadalupe. LAFAYE, Jacques. Quetzalcóatl y Guadalupe. La formación de la conciencia nacional en México. México, 1995 (1977), p. 12.

3 Rojas Mix, Miguel. La otra Guadalupe. La que viene de la región de la luz. Cáceres, 1996, pp. 5-11.

${ }^{4}$ LAFAYE, Jacques. Quetzalcóatl y Guadalupe..., pp. 390-391.
} 
de historia guadalupana dedicado a los indios. Otros fueron el jesuita Francisco de Florencia o el presbítero Cayetano Cabrera y Quintero, quien defendió la idea del autorretrato mariano.

Uno de los argumentos más empleados para exaltar la naturaleza divina del ayate era la belleza de la imagen. ${ }^{5}$ Su carácter milagroso suscitó polémica desde el principio. Uno de los acontecimientos más relevantes tuvo lugar el 20 de Marzo de 1666, cuando un grupo formado por anticuarios, pintores y médicos la examinaron llegando a la conclusión de que no podía proceder de mano humana. El pintor Miguel Cabrera publicó en 1756 un opúsculo en el que aportaba alegatos estéticos para acreditar su perfección y difundía su naturaleza celestial. ${ }^{6}$

La Virgen de Guadalupe quedó acuñada de forma invariable, tal y como aparecía estampada en el ayate: sobre un cúmulo de nubes, con corona y rodeada de rayos solares. Viste túnica rosa y un manto azul decorado con estrellas que le cubre la cabeza. Se apoya sobre la luna en cuarto creciente, sostenida por un ángel con las alas de color rojo, azul y amarillo. Su rasgo más distintivo es la piel morena como la de los indios, pero tiene facciones europeas.

Su tipo iconográfico deriva del de la Inmaculada Concepción. Antonio Valeriano se refería a ella en su historia de las apariciones como una Inmaculada india. "Para la Virgen de Guadalupe se importó el nombre de una virgen célebre en la Madre Patria, y de otro la imagen de la Inmaculada Concepción forjada en la España de la Contrarreforma". ${ }^{7}$ El escritor Servando Teresa de Mier afirmaba que el taller dirigido por el franciscano fray Pedro de Gante había producido en masa imágenes de la Virgen que Juan Diego había visto bajo el aspecto de una Inmaculada Concepción. ${ }^{8}$ Resulta paradójico que siendo uno de los temas más omnipresentes en la pintura barroca española apenas existieron representaciones de la Inmaculada en el virreinato. La razón es que su culto estaba implícito en el de la Virgen de Guadalupe: "la milagrosa imagen de Nuestra Señora de Guadalupe de México, es el misterio de la Purísima Concepción... y poniendo los ojos en la Santa Imagen ¿quien no ve que sus señas todas son de la Concepcion?". 9 También el bachiller Miguel Sánchez y el Padre Francisco de Florencia, el principal difusor de las imágenes novohispanas, sostuvieron esta tesis. ${ }^{10} \mathrm{El}$ historiador Antonio Moreno Garrido defiende la presencia simbólica en América de los tipos iconográficos concepcionistas andaluces. Para él el mejor ejemplo de lo que significó la Inmaculada en América es la Virgen de Guadalupe. ${ }^{11}$ Asimismo, Miguel Luis López Muñoz afirma que la Guadalupana responde a la iconografía concepcionista. ${ }^{12}$ Algunos grabados inmaculistas flamencos como los de Martín de Vos o Jerónimo Wierix pueden considerarse antecedentes iconográficos. ${ }^{13}$

\footnotetext{
${ }^{5}$ Según el historiador mexicano Juan Homero Illescas, el lienzo guarda uno de los ideales del arte pictográfico del clasicismo: la proporción áurea. IllesCAS HeRnÁNDEZ, Juan Homero. "La Virgen de Guadalupe y la proporción dorada", Catálogo de la exposición El Divino Pintor: la creación de María de Guadalupe en el taller celestial, Museo de la Basílica de Guadalupe, ciudad de México, Diciembre 2001-Abril 2002. México, 2001, p. 11.

${ }^{6}$ CABRERA, Miguel. Maravilla americana y conjunto de raras maravillas observadas con la dirección de las reglas del arte de la pintura en la prodigiosa imagen de Ntra. Señora de Guadalupe de México. México, 1977 (1756).

${ }^{7}$ SтогснітA, Víctor. "Imagen y aparición en la pintura española del Siglo de Oro y en la devoción popular del Nuevo Mundo", Norba-Arte. Badajoz, no 12, 1992, p. 96.

${ }^{8}$ Mier, Servando Teresa de. Memorias. Apología del Dr. Mier. México, t.1, 1946 (1822).

${ }^{9}$ CRUZ, Mateo de la. Relación de la milagrosa aparición de la Santa Imagen de la Virgen de Guadalupe de México, sacada de la historia que compuso el bachiller Miguel Sánchez. México, 1781 (1660), p. 22.

${ }^{10}$ Florencia, Francisco de. Estrella del Norte de México. México, 1982 (1688), p. 384. Según afirma Jacques Lafaye, de no mediar su identificación con la Inmaculada Concepción, la devoción guadalupana no habría alcanzado tanto auge en Nueva España. LAFAYE, Jacques. Quetzalcóatl y Guadalupe..., p. 399.

${ }^{11}$ Moreno Garrido, Antonio. "Algunas consideraciones entorno a la iconografía concepcionista en Andalucía y el Nuevo Mundo durante el siglo XVIII”, Andalucía y América en el siglo XVIII. Sevilla, 1985, pp. 183-189.

12 LÓPEZ MuÑoz, Miguel Luis. "Cofradías en Granada y América. Aproximación a su papel y relaciones”, El reino de Granada y el Nuevo Mundo, Congreso Internacional de Historia de América, Mayo 1992. Granada, vol. 1, 1994, p. 665.

13 CuAdriello, Jaime. Catálogo de la exposición El Divino Pintor..., p. 67.
} 
Según el investigador Manuel Trens, la iconografía de la Virgen de Guadalupe es de indudable ascendencia apocalíptica, lo que avala la tesis que la vincula a la Inmaculada Concepción. ${ }^{14}$ Desde el Concilio de Trento la doctrina inmaculista quedó asociada al tipo apocalíptico descrito por San Juan. "Apenas a principios del siglo XVI había quedado configurado ciertamente en el arte español el tipo iconográfico de la Tota Pulcra, del que sin duda se hizo eco la imagen del Tepeyac". ${ }^{15}$ Según Suzanne Stratton procede de la familia de la Tota Pulcra hispanoflamenca. ${ }^{16}$ Una de las composiciones más fieles al Apocalipsis es un grabado que realizó Alberto Durero para ilustrar Las revelaciones de San Juan. Incluía elementos como la luna menguante, las manos en actitud de oración, la corona, o los rayos solares que la rodean, que pasaron a formar parte de la iconografía guadalupana. El angelito que se sitúa a sus pies compendia de algún modo las presencias angélicas que menciona San Juan. La mandorla de nubes que la rodea señala su carácter de Tota Pulchra, aludiendo a su condición de aparecida. Una serie de grabados de procedencia europea sirvieron de modelo a la Virgen de Guadalupe y ponen de manifiesto su ascendencia apocalíptica. ${ }^{17}$ En "La Virgen preexistente alada con Raimundo Lulio y Duns Escoto", realizado en el siglo XVI en la Imprenta Guasp de Mallorca, la Virgen aparece con las manos unidas, lleva corona, y está rodeada por una aureola de rayos. Un grabado holandés fechado entre 1430 y 1440, publicado por Charles D. Cutler en Northern Painting from Pucelle to Brugel, incluye además una cabeza de querubín a los pies de la Virgen como es característico de la Guadalupana. Santiago Sebastián afirma que la iconografía de la Virgen del Apocalipsis se introdujo en América a través de grabados surgidos de dibujos de Juan de Jáuregui u obras de Rubens, en especial su "Virgen del Apocalipsis" de la Antigua Pinacoteca de Munich. ${ }^{18}$

Aunque su iconografía nada tiene que ver con la de la Virgen de Guadalupe de Extremadura, una talla románica en la que aparece sentada con el niño en su regazo, numerosos historiadores han apuntado una posible conexión con la imagen de Nuestra Señora de la Concepción que se conserva en el coro de la iglesia del santuario extremeño. Es una escultura en madera que representa a una virgen gótica apocalíptica con el niño en brazos, luce corona, se apoya sobre una luna menguante sostenida por un angelito, y está rodeada de rayos: "Porque quiso la Virgen, habiendo de poner a su imagen mexicana el nombre de Guadalupe, se copiase a imitación de esta de nuestro coro, y no de la célebre, antiquísima y principal portadora de este nombre, toca a los juicios de Dios, que no debemos investigar curiosos, si no es venerarlos rendidos". 19

La primera reproducción grabada de la Virgen de Guadalupe es la que realizó el flamenco Samuel Stradanus entre 1615 y 1620. En dos bandas longitudinales aparecen sus ocho milagros más célebres de la Virgen, en la parte central superior la Guadalupana, y en la inferior un epígrafe explicativo. Es la única representación conocida en la que carece de sus característicos rayos solares; en su lugar aparecen cabezas de querubines sobre un fondo de nubes. Una composición bastante novedosa figuraba en la portada de Imagen de la Virgen María, madre de Dios de Guadalupe del bachiller Miguel Sánchez, publicada en 1648. La Virgen estaba apoyada sobre un nopal, acompañada de dos ángeles arrodillados, un águila bicéfala y un escudo pontificio. Con ella se quería manifestar que contaba con el apoyo de las autoridades civiles y eclesiásticas. En la obra

14 Trens, Manuel. María. Iconografía de la Virgen en el arte español. Madrid, 1946, pp. 55-74.

15 Cuadriello, Jaime. Catálogo de la exposición El Divino Pintor..., p. 69.

16 Stratton, Suzanne. "La Inmaculada Concepción en el arte español", Cuadernos de Arte e Iconografía. Madrid, t. I, no 2, 1988, pp. 3-127.

17 Vargas Lugo, Elisa. "Iconología guadalupana”, Catálogo de la exposición Imágenes guadalupanas, cuatro siglos, Centro Cultural de Arte Contemporáneo, ciudad de México, Noviembre 1987-Marzo 1988. México, 1987, pp. 57-61.

18 Sebastián López, Santiago. El barroco iberoamericano. Mensaje iconográfico. Madrid, 1990, p. 141.

19 SAN José, fray Francisco de. Historia universal de la primitiva imagen de Nuestra Señora de Guadalupe. Madrid, 1743, p. 146. Según el etnohistoriador Eduardo Corona Sánchez, esta imagen y una serie de deidades prehispánicas dieron lugar a la Virgen de Guadalupe. 
Felicidad de México de Luis Becerra Tanco se incluía uno de 1675 atribuido a Antonio de Castro que mostraba el sol asomando tras la Virgen en el momento en que esta se aparecía a Juan Diego, sugiriendo que la sombra de los rayos solares produjo la estampación de la imagen guadalupana. Estos grabados ponen de manifiesto que en los primeros momentos no existía rigor en la iconografía guadalupana.

La imagen impresa en el ayate dio lugar a centenares de obras pictóricas en las que lo único que variaba eran los elementos que la acompañaban. En el siglo XVII la pintura novohispana tenía una función más devocional y social que artística. Junto a las temáticas europeas comenzaron a aparecer otras, autóctonas, entre las que pronto destacó la Virgen de Guadalupe. Todos los artistas virreinales la incluyeron en su repertorio, siendo algunos verdaderos difusores de su cualidad milagrosa. ${ }^{20}$

La más antigua e innovadora representación pictórica es la realizada por el español Baltasar de Echave Orio en 1606. ${ }^{21}$ Está realizada sobre tabla. Su semejanza con el original es enorme, con el fin de respaldar su naturaleza portentosa como indica el ayate. Sorprende que no tuviera más influencia en artistas posteriores. Su importancia radica en que se anticipa cuatro décadas a la aparición de las primeras obras aparicionistas impresas. ${ }^{22}$ Además, demuestra que las pinturas guadalupanas fueron anteriores a los grabados. Hasta 1987 se creía que el lienzo del Santo Desierto de San Luis de Potosí pintado por Lorenzo Delapyedra en 1625 era la primera, sin embargo dos obras localizadas por el historiador Manuel Ortiz alteraron esta convicción: la de Echave Orio, y un mural del Convento de Yuririapúndaro (Guanajuato) presuntamente realizado por fray Pedro Salguero entre 1621 y $1627 . .^{23}$

Todas las copias guadalupanas incluían un mensaje implícito que exaltaba su origen divino. Muchas de ellas eran "tocadas a su original" con el fin de adquirir sus propiedades milagrosas, siendo las más cotizadas. Según el historiador Jaime Cuadriello, la Virgen había sido investida de un culto aún más elevado que el de la madre de Dios y poseía unas cualidades especiales en base a su material y misterioso mecanismo de impresión. ${ }^{24}$

Entre los distintos modelos iconográficos, el más frecuente era el que exhibía en los ángulos los cuatro medallones con las tres apariciones de la Virgen al indio Juan Diego y el Milagro de las rosas, de gran carácter narrativo. En opinión de Elisa Vargas Lugo, Juan Correa fue el primer artista en incorporarlas en 1667 en un lienzo hoy conservado en el Museo de la Pasión de Valladolid. ${ }^{25}$ La iconografía de las apariciones quedó definida en los cuatro grabados que realizó el sevillano Matías de Arteaga y Alfaro en 1686 e ilustraron la obra Felicidad de México de Luis Becerra Tanco. En casos excepcionales aparecen en lienzos aparte, rodeando al principal. En el Museo Nacional de Querétaro existe una muestra. Con el tiempo la escena del milagro llegó a representarse de forma autónoma, como el pintado por Francisco Martínez para la Iglesia de los Jesuitas de Zacatecas (México).

Otro elemento iconográfico que surgió en el siglo XVII es el enmarcamiento de rosas, que puede incluir otras variedades de flores y alude a las guirnaldas que los indios ponían ante la imagen de la Virgen. También de esta época data la incorporación de ángeles y arcángeles. En el siglo

20 Especialmente Juan Correa y Miguel Cabrera, conocido por su devoción guadalupana y que realizó en la Colegiata de Guadalupe trabajos de ornato litúrgico.

21 Vera, Fortino Hipólito. Tesoro guadalupano. México, 1887.

${ }^{22}$ El historiador Manuel Ortiz es uno de los que la estudió con detenimiento. ORTIZ VAQUERo, Manuel. "Pintura guadalupana. Tres ejemplos”, Imágenes guadalupanas, cuatro siglos. México, 1987, p. 29.

23 VARGas Lugo, Elisa. “Algunas notas más sobre iconografía guadalupana”..., pp. 59-66.

24 Cuadriello, Jaime. Catálogo de la exposición El Divino Pintor..., pp. 75-80.

25 VARGAS Lugo, Elisa. “Algunas notas más sobre iconografía guadalupana”..., p. 63. Para Santiago Sebastián la más antigua es la situada en la Capilla de San Onofre de Sevilla, de Juan Correa. SEbastián, Santiago. "El tema de la Virgen de Guadalupe en Juan Correa”, Anales del Instituto de Investigaciones Estéticas. México, no 46, 1976, pp. 65-66. 
XVIII se delimitó un espacio en la parte central inferior del lienzo en el que pueden aparecer tres tipos de escenas: San Juan escribiendo el Apocalipsis, una composición derivada del texto de Miguel Sánchez; la aparición de la Virgen a Juan Bernardino, el tío enfermo de Juan Diego; o el Santuario de Guadalupe en el Monte Tepeyac, la más frecuente. ${ }^{26}$

Con los temas bíblicos se reclamaba el suceso de las apariciones como providencial y exclusivo de esa tierra. Una serie de variantes iconográficas relacionadas con el sentimiento patriótico y la lucha contra la idolatría asociaban a la Virgen de Guadalupe con el Arcángel San Miguel. Miguel Cabrera ideó una composición que inspiró multitud de versiones en la que este sostenía a la Virgen, sobre la que aparecía la Santísima Trinidad. Su significación como culto simbólico de la ciudad de México originó obras como "Traslado de la imagen de la Virgen de Guadalupe a la primera ermita y primer milagro", localizada en el Museo de la Basílica de Guadalupe. Recoge la festividad de este acontecimiento, en el que un indio había sido herido por una flecha y sanado por la Virgen.

En el siglo XVIII se realizaron las más ricas alegorías guadalupanas. En el Museo Franz Mayer de la ciudad de México se exhibe un óleo en el que se observan, junto a la Virgen, escenas que representan la Escala de Jacob, San Juan escribiendo el Apocalipsis, la Jerusalén celeste, y en la cúspide, la Santísima Trinidad. En la Catedral de Morelia (México) se ubica un lienzo llamado "Epifanía guadalupana", con una inusual temática consistente en situar a los pies de la Virgen a los tres Reyes Magos. Otra obra interesante es "María Inmaculada Reina del Cielo", en la que la Virgen de Guadalupe está coronada por la Trinidad antropomorfa y rodeada de símbolos de pureza. ${ }^{27}$

Las pinturas de trasfondo político alcanzaron gran popularidad. En una obra titulada "La Virgen de Guadalupe como fuente de la Divina Gracia" la Virgen se encuentra sobre una fuente de la que beben personajes de "las dos Españas". En una composición de Juan Patricio Morlete inspirada en un grabado que Juan Sebastián Klauber realizó para conmemorar el patronato de la Virgen de Guadalupe, aparece rodeada de santos, profetas, ángeles... que le ofrecen sus coronas.

Una interesante temática que aunque polémica no fue censurada en el virreinato es el "taller celestial". Mostraba a un anciano Padre Eterno pintando a la Virgen de Guadalupe y reclamando así su autoría. ${ }^{28}$ Este tipo de composiciones tenían su precedente en el "taller de San Lucas". ${ }^{29}$ Con ellas se pretendía trasmitir que San Lucas era un excelente pintor cristiano. Dios era a veces asistido por otras personalidades divinas o por el indio Juan Diego. En una de estas obras, pintada por Miguel Cabrera en 1759 y conservada en el Museo de la Basílica de Guadalupe, aparece la Santísima Trinidad y un grupo de angelitos. En otra variante, la personificación humana del Espíritu Santo pintaba a la Virgen. ${ }^{30}$

\footnotetext{
26 Según el historiador José Guadalupe Victoria, la inclusión de la imagen del Santuario tenía un significado trascendental para los criollos novohispanos. Con ello manifestaban que habían cumplido el principal deseo de la Virgen: su construcción. Victoria, José Guadalupe. "Un singular ejemplo de piedad mariana. Notas entorno a una pintura de la Virgen de Guadalupe", Anales del Instituto de Investigaciones Estéticas. México, nº 60, 1989, p. 76.

${ }^{27}$ La Trinidad Antropomorfa aunque fue una iconografía considerada herética en España alcanzó gran difusión en Nueva España. Estaba encarnada por tres hombres iguales diferenciados por los colores de sus ropajes y los atributos que llevaban en el pecho. Aludía a la humanidad de Jesús. En las parroquias de San Pedro y Santiago de Puente la Reina (Pamplona) y en el Convento de las Clarisas de Estella (Pamplona) se encuentran representaciones atribuidas a Miguel Cabrera.

28 Para el pintor y tratadista Antonio Palomino, Dios había sido el primer pintor. El propósito de esta afirmación era exaltar la nobleza del arte de la pintura. PALomino, Antonio. El museo pictórico y escala óptica. Madrid, 1988 (1715). Partiendo de esta obra, el pintor Miguel Cabrera argumentaba en Maravilla americana... la antigüedad del arte pictórico, su carácter intelectual y su cualidad de vehículo divino. La Virgen de Guadalupe fue la imagen más empleada por los pintores novohispanos para exaltar la nobleza de su arte.

29 A principios del siglo XVII, el teórico y pintor Vicente Carducho divulgaba esta leyenda. Carducho, Vicente. Diálogos de la pintura. Madrid, 1979 (1633), p. 374.

30 En opinión de Jaime Cuadriello era la defensa de la tesis inmaculista la que posibilitaba que Dios adoptara el rol de pintor y protagonizara una iconografía que en otro contexto habría sido una aberración. CuAdRIELlo, Jaime. Catálogo de la exposición El Divino Pintor..., pp. 163-165.
} 
Muchas pinturas fueron exportadas al extranjero, especialmente a España. Los franciscanos introdujeron la devoción guadalupana, posteriormente difundida por los jesuitas. Arraigó especialmente en Andalucía, a cuyos puertos arribaron centenares de representaciones pictóricas. En palabras del Padre Francisco de Florencia: "En Cádiz, en Sevilla... es tan conocida, tan venerada y aplaudida esta santa imagen, que apenas hay casa en que no la tengan". Pero encontramos ejemplares en casi todas las provincias españolas. La historiadora María Concepción García Sáiz afirma que es rara la iglesia, catedral o pequeña parroquia de pueblo, que no albergue alguna pintura de la Virgen de Guadalupe salida de los talleres novohispanos.

Aunque aquí no existe la diversidad iconográfica que encontramos en México, podemos distinguir varios modelos. Joaquín González Moreno establece tres grupos principales refiriéndose a las localizadas en Andalucía: el de las apariciones, el de los ángeles y el del paisaje, a menudo combinados entre sí. ${ }^{31}$ También el investigador mexicano Jaime Cuadriello publicó un estudio sobre la pintura guadalupana en España, agrupándola según su iconografía. ${ }^{32}$ En función de los elementos que acompañan a la Virgen, podemos diferenciar tres modalidades de representaciones guadalupanas:

\section{1. "Fieles copias del original"}

Así llamadas en base a su similitud con la imagen estampada en el ayate. Prescinden de las escenas de las apariciones y de cualquier otro elemento ornamental. La mayoría datan del siglo XVII. Aunque suelen ser muy similares entre sí, se constatan algunas peculiaridades.

En el Convento de San Felipe Neri de Palma de Mallorca se localiza una en la que aparecen ramos de flores a ambos lados de la Virgen. En la que se ubica en el Convento de Concepcionistas Recoletas de Tafalla (Pamplona), firmada por Juan Salguero, llama la atención que la Virgen no tiene corona. Lo mismo sucede en una ubicada en el Convento de Concepcionistas Recoletas de Estella (Pamplona). Las conservadas en la Iglesia de San Andrés de Morentín (Pamplona) y Santa María de Zúñiga (Pamplona), obra de José de Páez, tienen la corona diferenciada. En el Convento de las Madres Mercedarias de Santiago de Compostela se custodia un lienzo enmarcado por un dosel de tela bordado que pretende sugerir que se trata de la imagen estampada en el ayate. En el Museo de América de Madrid se exhibe una pintura realizada por Francisco Martínez en la que la Virgen está rodeada por una guirnalda de rosas. El autor utiliza el tono oscuro de la piel para subrayar su condición indígena. Una inscripción lo acredita como verdadero retrato de Nuestra Señora de Guadalupe. La situada en la Catedral de Valencia, obra de José de Ibarra, incluye otra que indica que fue "tocada a su original". En la Parroquia de San Nicolás de Tudela (Pamplona) hay una representación firmada por Antonio de Torres que al parecer es un calco del original. ${ }^{33}$ En una de fray Miguel de Herrera que se encuentra en el Beaterio de la Santísima Trinidad de Sevilla se observa una filactelia a los pies de la Virgen que reza: "Non fecit taliter omni nationi" (No hizo lo mismo con otras naciones). También el lienzo de Juan de Villegas que se expone en el Museo de América lleva esta inscripción. En la Iglesia de San Ildefonso de Jaén se sitúa una pintura de enorme interés, pues según afirma el historiador Rafael Ortega se trata de la primera representación de la Virgen de Guadalupe. Parece ser que la pintó fray Juan Bautista Moya. ${ }^{34}$ Su

\footnotetext{
31 GonZÁlez Moreno, Joaquín. Iconografía guadalupana en Andalucía..., pp. 17-38.

32 Cuadriello, Jaime. "La propagación de las devociones novohispanas: las Guadalupanas y otras imágenes preferentes", Discursos en el Arte. XV Coloquio Internacional de Historia del Arte. México, 1991, pp. 268-288.

33 Heredia Moreno, Ma del Carmen, Orbe Sivatte, Antonia y Orbe Sivatte, Mercedes. Arte Hispanoamericano en Navarra. Pamplona, 1992.

34 ORTEGA Y SAGRISTA, Rafael. "Una reproducción de la Virgen de Guadalupe en la Iglesia de San Ildefonso de Jaén", Senda de Huertos, $n^{o}$ 18, Molina Martínez, Miguel. "El Santo Reino, centro de irradiación de fe", Reino de Granada. La aventura americana. Granada, t. III, 1991, p. 112. Muy pocas pinturas pertenecientes a este tipo iconográfico se conservan en Andalucía. En cambio son frecuentes en Burgos, Navarra, el País Vasco...
} 
iconografía es sorprendentemente primitiva, y tanto el angelito como la corona de la Virgen son totalmente diferentes a los del modelo tradicional.

\section{Con las escenas de las apariciones}

Es el grupo más común. A él pertenecen obras que presentan en sus ángulos cuatro cartelas que narran la secuencia de las apariciones y el milagro. Generalmente se sitúan de izquierda a derecha para facilitar su lectura. Suelen ir acompañadas de rosas y/o angelitos, y en ocasiones de una vista del Santuario del Tepeyac a los pies de la Virgen. En 1761 don José Mariano de Veytia escribía que "en la mayor parte de estos cuadros estaban pintadas las apariciones". ${ }^{35}$ Según Joaquín González Moreno, el ochenta por ciento de las imágenes del siglo XVIII existentes en España poseen las tradicionales cartelas. ${ }^{36}$

En la Iglesia de las Monjas Claras de La Laguna (Tenerife) se conserva una pintura en la que la Virgen está rodeada por una guirnalda de rosas e incluye una imagen del santuario. En la Colegiata de Berlanga del Duero (Soria) existe una en la que aparece un magnífico retrato del donante, algo poco habitual. ${ }^{37}$ La Virgen de Guadalupe que se encuentra en el ex Convento de Nuestra Señora del Carmen de Sanlúcar la Mayor (Sevilla) está rodeada de símbolos que aluden a su pureza. Una de las muestras más valiosas es la pintada por Cristóbal de Villalpando que pertenece a una colección privada sevillana. Sus escenas de las apariciones son de una enorme perfección y exactitud. A ambos lados de la Virgen, a sus pies y sobre su cabeza figuran cuatro óvalos con paisajes o monumentos del Tepeyac. El resto del lienzo está cubierto por una decoración geométrica de gran originalidad.

La presencia de angelitos es casi una constante. A veces portan símbolos marianos o sostienen las cartelas. Con frecuencia poseían la impronta de la escuela sevillana, pero desde la fundación de la Academia de Pintores de México en 1753 prevalecieron los tipos italianos. Algunos, como los de Juan Correa, presentaban además rasgos indígenas. La obra más antigua conservada en España en la que la Virgen está rodeada de ángeles es un óleo de José de la Cruz que pertenece a una colección particular sevillana. La Virgen de Guadalupe que se sitúa en el Convento de Santa María de Cádiz está rodeada de ángeles. Un ejemplar bastante interesante se localiza en la Iglesia de San Juan Bautista de Murcia. Se trata de una obra de Miguel Cabrera en la que las escenas de las apariciones están sostenidas por ángeles alados. El investigador Joaquín González Moreno declara: "Ninguna de las representaciones pictóricas por mí conocidas en España de la mexicana Virgen de Guadalupe posee las excelencias y el magisterio de la venerada en la iglesia parroquial de San Juan Bautista de Murcia". ${ }^{38}$ En el Convento de las Clarisas Capuchinas de Plasencia (Cáceres) se custodia un óleo sobre tabla realizado por Juan Patricio Morlete, en el que se aprecian cuatro angelitos y guirnaldas de flores. En la pintura situada en el Colegio de la Enseñanza de Tudela (Pamplona), obra de Antonio de Torres, los ángeles portan símbolos marianos.

A veces las composiciones se inspiraban en grabados europeos. En la Catedral de Santiago de Compostela se conserva una pintura de Juan Patricio Morlete que revela la influencia de los grabados de los hermanos Klauber. Se trata de una obra de excelente dibujo y composición equilibrada en la que se constata el influjo de Miguel Cabrera. Los marcos de las escenas de las apariciones y los angelitos que las rodean responden a la estética rococó. Existe una curiosa relación

\footnotetext{
35 CUADRIEllo, Jaime. "Tierra de prodigios: la ventura como destino", Los pinceles de la historia. El origen del reino de Nueva España. México, 1999, pp. 180-228.

36 GONZÁLEZ MORENO, Joaquín. Iconografía guadalupana en Andalucía, p. 17.

37 Podemos considerar un precedente de esta iconografía "La Inmaculada con Miguel Cid" de Francisco Pacheco, situada en la Catedral de Sevilla.

38 GonZÁlez Moreno, Joaquín. Iconografía guadalupana en Andalucía..., p. 65.
} 
entre la pintura enconchada (con incrustaciones de concha de nácar) que se custodia en el Convento de Monjas Capuchinas de Castellón de la Plana y otra situada en la Parroquia de San José de Tlaxcala (México), pues la escena del ángulo inferior derecho parece proceder de la misma estampa. En ella aparece el obispo bajo un baldaquín, y el muro cubierto por una rica tela con lienzos. ${ }^{39}$

Las cartelas de las apariciones eran con frecuencia de forma oval, aunque también podía ser poligonal. ${ }^{40}$ Las de José de Alcíbar y Juan de Villegas que se exhiben en el Museo de América de Madrid presentan las escenas de las apariciones en marcos octogonales. También Antonio de Torres prefirió encuadrarlas en octógonos. Desde 1760 se popularizaron las molduras de rocalla. En la que se encuentra en el Convento de Santa Clara de Palencia los medallones son pequeños cuadros enmarcados en espejos rococó sostenidos por ángeles. En la situada en el Convento de las Carmelitas de Araceli de Corella (Pamplona), de forma octogonal, las cartelas están enlazadas por guirnaldas vegetales y el alargamiento de la mandorla permite la inclusión de la paloma del Espíritu Santo sobre su cabeza. ${ }^{41}$

En ocasiones contadas figuraban junto a la Virgen de Guadalupe personajes bíblicos. En el lienzo de Juan Patricio Morlete situado en la Parroquia de Santa María de Uribarri de Durango (Vizcaya), está guarnecida por los arcángeles San Miguel y San Gabriel y es coronada por la Santísima Trinidad. En la Iglesia de Santa Catalina de Tacoronte (Tenerife) se encuentra una pintura sobre lámina de cobre obra de José de Páez en la que la Virgen también es coronada por la Santísima Trinidad representada por tres figuras masculinas. A sus pies aparece una escena de la Huida a Egipto, un tema conocido en Nueva España como Nuestra Señora del Destierro. Otra composición bastante original es la que se localiza en la Catedral de Palencia, de Manuel Osorio, de estética rococó. En ella la Guadalupana está acompañada por las imágenes de la Virgen de Loreto, de la Piedad y de los Remedios, denominadas los baluartes de la ciudad de México. ${ }^{42}$ En la Capilla de San José de Sevilla se encuentra una pintura en la que la Virgen de Guadalupe está flanqueada por San José y San Cristóbal, ambos con el niño Jesús en brazos, actuando como intercesores de Dios. Parecen ser añadidos posteriores, pues en la iglesia hubo dos esculturas de esos santos que pudieron servirle de modelo. Un lienzo que se encuentra en la Iglesia de San Miguel de Villalón de Campos (Valladolid) incluye a ambos lados de la Virgen a los arcángeles Gabriel y Uriel. A sus pies vemos una quinta escena dedicada a la curación de Juan Bernardino. La presencia de arcángeles en torno a la Virgen se aprecia también en un lienzo conservado en el Museo de la Basílica de Guadalupe, aludiendo a su carácter de mediadora en la Redención. El Museo de América posee interesantes representaciones como la de Juan de San Pedro Flores, en la que vemos a Dios Padre con los brazos extendidos sobre la Virgen, a sus lados las figuras de Santa Ana y San Pedro de Alcántara, y a sus pies dos angelitos sosteniendo un rosario. ${ }^{43}$ En una colección

39 García SÁrz, María Concepción y SERRERA, Juan Miguel. "Aportaciones al catálogo de enconchados”, Cuadernos de Arte Colonial. Madrid, $n^{\circ}$ 6, 1990, pp. 55-85.

40 Según dice Joaquín González Moreno, hasta 1760 es frecuente encontrar la forma poligonal en los medallones. Los óvalos, octógonos y rectángulos en los que iban insertas las escenas de las apariciones estaban rodeados por una gruesa línea dorada con filos negros. GonZÁLEZ Moreno, Joaquín. Iconografía guadalupana en Andalucía..., pp. 17-18.

${ }^{41}$ La presencia del Espíritu Santo en forma de paloma simboliza el vínculo entre el Padre y el Hijo, otorgando a la Virgen la condición de Madre de Cristo y Madre de Dios.

42 Esta obra se inspira en una compleja alegoría situada en la Pinacoteca Virreinal de San Diego que figuró en la exposición "Las Guadalupanas más bellas", celebrada en el Centro Cultural de Arte Contemporáneo de México entre 1987 y 1988. En ella aparecen las cuatro imágenes marianas que según el jesuita Francisco de Florencia protegían la ciudad de México. La Virgen de Guadalupe aventajaba a las demás por ser el norte. Fernández De EcheVerría Y Veytia, Mariano. Baluartes de México. Descripción histórica de las cuatro milagrosas imágenes de Nuestra Señora que se veneran en la тиy noble, leal e imperial ciudad de México, capital de la Nueva España. México, 1820 (1778).

${ }^{43}$ La aparición de Dios sobre la Virgen de Guadalupe avala su carácter de Inmaculada Concepción. Una novedad que introduce esta pintura es unirla a devociones españolas como Santa Teresa y San Juan de la Cruz. Otra es su identificación 
particular malagueña se conserva un óleo que representa a la Virgen de Guadalupe acompañada de San Diego de Alcalá, el apóstol San Andrés y San Francisco de Asís. ${ }^{44}$

Las escenas de las apariciones presentan en general escasas variaciones. Uno de los casos más insólitos lo encontramos en la pintura que se conserva en la Iglesia parroquial de Quincoces de Yuso (Burgos), pues en dos de ellas figura un ángel. En un lienzo situado en el Convento de San Leandro de Sevilla, obra de Juan Correa, el orden de las apariciones está modificado. El que se encuentra en la Iglesia parroquial de San Pedro de Tavira (Burgos) no incluye el característico angelito a los pies de la Virgen. El de la Iglesia de Santa Eulalia de Belandia (Orduña, Vizcaya) ostenta la peculiaridad de mostrar las escenas de las apariciones numeradas, lo que también se constata en la pintura de la Iglesia de San Nicolás de Bari de Sevilla. En la Iglesia parroquial de San Eustaquio de Sanlúcar la Mayor (Sevilla) se conserva un lienzo de Ambrosio de Avellaneda en el que por única vez se representa en la tercera cartela a la Virgen impresa en el ayate de Juan Diego. La pintura situada en el Convento de Santa María de Cádiz muestra las cartelas unidas en la parte inferior, formando un gran rectángulo dividido por ribetes dorados paralelos en cuatro partes iguales. Esto se observa también en la que se sitúa en la Catedral de Astorga (León). En una colección particular sevillana se encuentra una obra de Antonio de Torres en cuyo tercer medallón aparece Juan Diego corriendo por el Tepeyac como segundo término del mismo tema.

A partir de la segunda mitad del siglo XVII se comenzó a añadir la escena del Tepeyac, gracias a la que se pueden conocer los distintos santuarios dedicados a la Virgen. Este recurso ya se empleaba en la pintura andaluza. El paisaje más antiguo conservado en España es el que aparece en la Guadalupana que se ubica en el Convento de Nuestra Señora de Loreto de Espartinas (Sevi1la), realizada por José Rodríguez Carnero. Muestra el segundo templo dedicado a la Virgen, la Casa de Novenas, la Parroquia de los Indios y el cementerio. El lienzo del Convento del Pozo Santo de Sevilla parece ser una copia de este. El situado en la Capilla de San José de Sevilla ofrece un paisaje inédito del Tepeyac. En el de la pintura conservada en la Hermandad de la Santa Caridad de Sevilla aparece por primera vez la carretera que comunicaba el Santuario con la ciudad y un pórtico en la plazoleta. También figuran la Casa de Ejercicios y la Parroquia de los Indios. Llama la atención la ausencia de las escenas de las apariciones. En la que se encuentra en el Convento de Santa Teresa de Sevilla pueden verse la Plaza Real y los diez primeros torreones marianos dedicados al Rosario, además de las Capillas del Cerrito y del Pocito. En la del ex Convento de Nuestra Señora de la Paz de Sevilla se aprecia más interés en el paisaje en sí que en los monumentos. En la iglesia del Convento de San José del Carmen de Sevilla existe una en la que vemos una nueva interpretación del paisaje del Tepeyac. Un grupo de serafines y querubines llena las tres primeras cartelas, algunos llevando instrumentos musicales. Además, en la primera aparece una bandada de pájaros que según la investigadora María Luisa Cano simbolizan las aves cuyos cantos eran parecidos a la música celestial que escuchó Juan Diego. ${ }^{45}$ En el Convento de Nuestra Señora de los Ángeles de Constantina (Sevilla) se encuentra una que incluye en cada cartela un rótulo que indica el paisaje que representa. Algo similar sucede con la situada en el ex Convento de Carmelitas de Sanlúcar la Mayor (Sevilla), de Pedro López Calderón, en la que se explica en una cartela los monumentos retratados. Posee una inscripción en la que se lee: "Descripción del/sitio en que se venera la SS./Ymagen de Guadalupe, una legua/de la Ciudad de México".

con la Virgen del Rosario. En una colección particular malagueña existe una pintura del mismo autor, prácticamente idéntica a esta. Clavijo García, Agustín. "Pintura colonial en Málaga y su provincia", Andalucía y América en el siglo XVIII. Sevilla, 1985, p. 101.

44 Clavijo García, Agustín. "Pintura colonial en Málaga y su provincia"..., p. 111.

45 Cano Navas, María Luisa. El convento de San José del Carmen de Sevilla. Sevilla, 1984, pp. 144-145. Este es un detalle único en las representaciones situadas en España. Un siglo después Miguel Cabrera pintó una bandada de pájaros similares para una obra situada en la Capilla del Cerrito del Monte Tepeyac. 
Posteriormente se le añadió otra: "Non fecit taliter omni nationi, sed mexicanae soli". Es probable que se inspirara en un grabado de un mapa del Tepeyac que reprodujo el Padre Cuevas y se custodia en el Archivo General de Indias de Sevilla. Tanto en la ubicada en el ex Convento de Capuchinos de Cádiz como en una de las que se encuentra en la Iglesia de Nuestra Señora de la Caridad de Sanlúcar de Barrameda (Cádiz), el Tepeyac aparece sin cartela.

A partir de la segunda mitad del siglo XVII la figura de la Virgen gana movilidad y es frecuente verla en la tercera escena ofreciéndole flores a Juan Diego. Podemos apreciarlo en la pintura situada en la Capilla de San Onofre de Sevilla. También en esta época se empezaron a colocar angelitos músicos junto a los medallones. A medida que transcurre el siglo XVIII se presta mayor atención a la escena del milagro. Los personajes se representan de forma individual y es posible discernir la mano de cada artista. El lienzo situado en el Colegio de Santa Cruz de Cádiz ofrece la mejor representación de las escenas de las apariciones. Está parcialmente destruido. Excepcionalmente tenía seis cartelas, de las que conserva cinco. En la primera se retrata un pasaje inédito: el alma de Juan Diego es transportada a los cielos por ángeles. La Virgen espera recibirla en una nube, y dos sacerdotes son testigos. El tercer medallón lo ocupa la aparición de la Virgen a Juan Bernardino.

En algunos casos, los rasgos de las escenas permiten asociar la obra con un determinado autor. Esto ocurre con la pintura localizada en la Iglesia de La Granada de Llerena (Badajoz). Las cartelas tienen marcos ochavados y en la parte inferior figura un medallón oval con un paisaje de la Villa de Guadalupe. ${ }^{46}$ En la Iglesia de San Francisco de Santa Cruz de la Palma (Islas Canarias) se custodia una Guadalupana que por la disposición de las apariciones podría ser obra de José de Alcíbar. En el lienzo conservado en la Iglesia parroquial de Cogeces de Monte (Valladolid), en el que se lee una inscripción que lo avala como "traçado all'original", las escenas de las apariciones se asemejan a las de una pintura de la Pinacoteca Virreinal de México que formó parte de la exposición Imágenes guadalupanas. Cuatro siglos, celebrada entre 1987 y 1988 en el Centro Cultural de Arte Contemporáneo de México.

La mayoría de los artistas imprimieron a sus pinturas guadalupanas su sello personal. Juan Correa restauró el original, aprovechando para realizar un calco en papel aceitado. Gracias a ello fue el artista que mayor exactitud la pintó. Sus representaciones poseen rasgos comunes como el cuidado en las facciones y la tez muy oscura. En las de Juan Diego quiso destacar su condición indígena a través del físico. ${ }^{47}$ El lienzo de la Iglesia de San Nicolás de Bari de Sevilla es para muchos historiadores la mejor y más novedosa de sus obras. Por sus dimensiones, formato horizontal y factura parece pintada para una catedral. Es de gran profusión decorativa, con un sentido taumatúrgico. La composición está dividida en tres partes iguales. Las escenas de las apariciones van numeradas e insertas en óvalos rodeados por guirnaldas de rosas. Como elemento innovador, la Virgen le entrega a Juan Diego un ramo de flores en la tercera escena. Otra característica de las guadalupanas de Correa es la importancia que le concede al Tepeyac, presente en casi todas sus pinturas con tal exhaustividad que se cree que debió vivir cerca del Santuario. La situada en la Iglesia de San Pedro de Ciudad Rodrigo (Salamanca) ofrece una imagen del cerro con la Basílica y la Calzada de los Misterios, presentes en otras representaciones suyas conservadas en España. En la Capilla de San Onofre de Sevilla se ubica una cuyo paisaje se considera un compendio de los pintados en el siglo XVII. Es el más completo, pues incluye los quince monumentos marianos.

\footnotetext{
46 En opinión Cristina Esteras, si tenemos en cuenta la predilección del pintor Antonio de Torres por los medallones ochavados, podría pensarse en él o en alguno de sus discípulos como autor. Esteras MarTín, Cristina. "Presencia del arte novohispano en la Baja Extremadura", Hernán Cortés, hombre de empresa. Primer congreso de americanistas. Badajoz, 1985, p. 289.

${ }^{47}$ Maquívar, María del Consuelo (Coordinadora). Memoria del Coloquio El arte en tiempos de Juan Correa. México, 1994, pp. 80-81.
} 
Miguel Cabrera, el más importante pintor guadalupano del siglo XVIII, examinó varias veces la imagen original, sacando también un calco. El aire rococó de sus vírgenes de Guadalupe deriva de los grabados de la escuela de Augsburgo.

En ocasiones algún elemento de la pintura revela la influencia de otro artista. En un lienzo situado en el Convento de San Juan de Dios de Cádiz dos angelitos se apoyan en las cartelas inferiores y otros dos sostienen las superiores. En ellos se aprecia la influencia de los de Murillo. También los de la pintura de la Iglesia de San Nicolás de Bari de Sevilla y los de la que se encuentra en el Convento de las Descalzas de Sanlúcar de Barrameda (Cádiz) tienen resabios murillescos. En el gaditano Colegio de Santa Cruz se ubica un lienzo cuyos ángeles evidencian el parecido iconográfico con los de Valdés Leal. Lo mismo sucede con los de los emplazados en la Iglesia de San Agustín y el ex Convento de Capuchinos de Cádiz. En el Convento de Concepcionistas de El Puerto de Santa María (Cádiz) y en la Iglesia del Carmen de Sanlúcar de Barrameda (Cádiz) se custodian sendas pinturas cuyos ángeles recuerdan a los de Francisco Pacheco. ${ }^{48}$

\section{Iconografias alternativas}

A este grupo pertenecen pinturas que presentan novedades con respecto a los modelos tradicionales. En ocasiones lo que varía es la composición, y en otras la forma o el soporte.

Existen casos en los que las escenas de las apariciones aparecen en lienzos individuales, rodeando a uno con la figura de la Virgen. Se conservan ejemplos en la Mezquita-Catedral de Córdoba, en la Capilla de Jesús de Conil de la Frontera (Cádiz), y en la Iglesia de San Andrés de Morentín (Pamplona), donde las apariciones indican su orden con un número. En la Iglesia de San Salvador de Guetaria (Guipúzcoa) hay un altar dedicado a la Virgen de Guadalupe compuesto por seis lienzos con las escenas de las apariciones. Un interesante ejemplar se conserva en el Convento de las Madres Concepcionistas de Ágreda (Soria). Es una especie de retablo tríptico de grandes dimensiones en el que las cuatro apariciones se sitúan fuera del cuadro de la Virgen, dos a cada lado, acompañadas de cartelas descriptivas. Además lleva una inscripción que lo acredita como "Retrato Verdadero y copia puntual de la imagen de Nuestra Señora de Guadalupe milagrosamente aparecida en la ciudad de Méjico a 12 de diciembre de 1531”. Las figuras son de gran expresividad y mantienen diálogos místicos. En el templo de San Mateo Texcalyacac (Estado de México) existe una pintura de Juan Correa con esta iconografía.

En el Museo de la Colegiata de San Luis de Villagarcía de Campos (Valladolid) se halla una obra atribuida a Juan Dualde que representa la escena de la Cuarta Aparición concebida de forma autónoma. Es una de las primeras ocasiones en las que Juan Diego despliega su túnica, que daría lugar al emblema de la Colegiata de Guadalupe. Tras el obispo de México, fray Juan de Zumárraga, vemos a fray Pedro de Gante, al virrey don Luis de Velasco y a su hijo. En el Convento de las Madres Carmelitas de Alba de Tormes (Salamanca) se conserva un lienzo del pintor Simón Peti que representa a Juan Diego mostrando el ayate con la imagen de la Virgen de Guadalupe a fray Juan de Zumárraga. Las fisionomías parecen corresponder a nativos. En la Iglesia de San Miguel de Jerez de la Frontera (Cádiz) se halla un cuadro de la Primera aparición. Muestra a la Virgen de Guadalupe como es habitual, y a Juan Diego arrodillado en el ángulo inferior izquierdo. En la Iglesia de Santa María la Blanca de Sevilla se localizan dos lienzos compañeros. Uno representa la Primera y la Tercera aparición y el otro la Segunda y la Cuarta. En la escena del Milagro de las rosas se pueden apreciar los mejores retratos de la iconografía de las apariciones guadalupanas.

\footnotetext{
48 Joaquín González Moreno afirma que la mayoría de las pinturas guadalupanas conservadas en España que incluyen ángeles se encuentran en Cádiz. González Moreno, Joaquín. Iconografía guadalupana en Andalucía..., p. 27.
} 


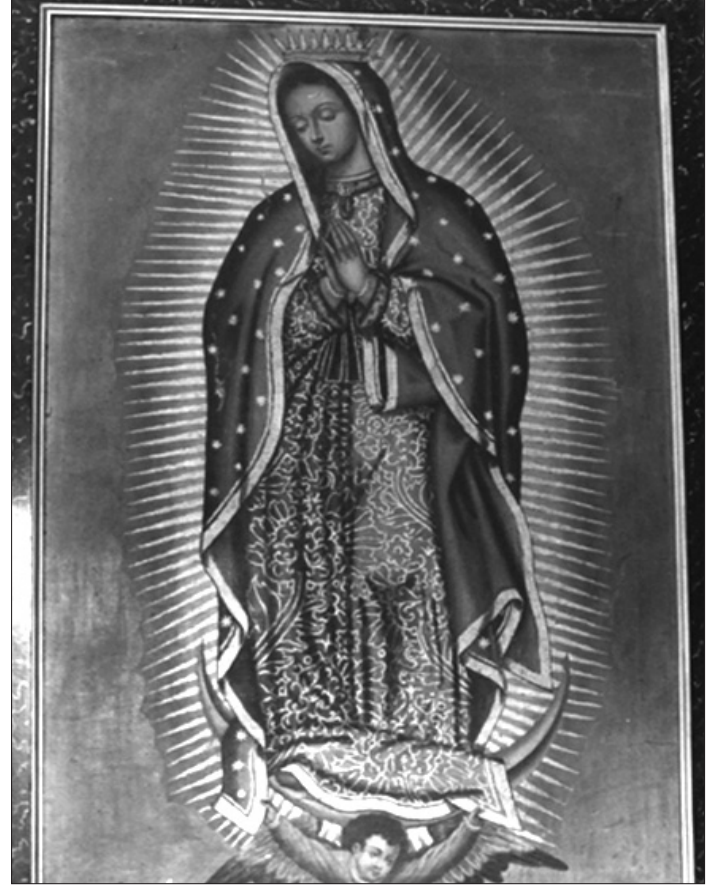

Fig. 1. Virgen de Guadalupe. Convento de las Concepcionistas Franciscanas de la Encarnación. Mondoñedo (Lugo). Anónimo. S. XVII.

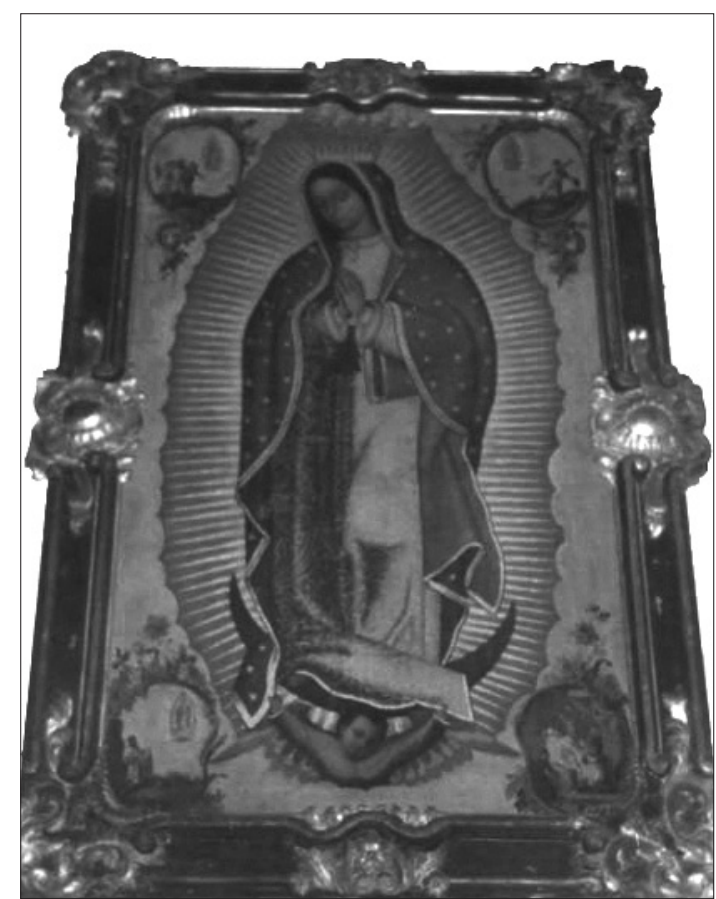

Fig. 2. Virgen de Guadalupe. Iglesia de la Victoria Medina Sidonia (Cádiz). Anónimo. S. XVIII.

A veces la novedad viene dada por las figuras que acompañan a la Virgen. En el Museo de América se custodia un lienzo enconchado (con incrustaciones de concha de nácar, según una técnica oriental) de Miguel González que nos ofrece una interesante composición. La Virgen de Guadalupe está rodeada por seis medallones. Los dos superiores representan a San Joaquín y Santa Ana, los dos del centro a San Francisco de Asís y San Buenaventura, y los inferiores a San Juan Bautista y San Juan Evangelista. Sobre la Virgen se encuentra el Padre Eterno y el Espíritu Santo, y bajo ella la figura recostada del rey David. Su propósito es entroncar a la Guadalupana con la dinastía davídica. En una colección particular malagueña existe un copia de esta pintura. ${ }^{49}$ Este tema también aparece en un lienzo ubicado en el Santuario de Guadalupe de Acámbaro (Guanajuato, México). En la Iglesia parroquial de Nuestra Señora de la O de Sanlúcar de Barrameda (Cádiz) existió uno con la figura de su donante a los pies rodeado de los tradicionales símbolos marianos. En el Convento de las Carmelitas Descalzas de Peñaranda de Bracamonte (Salamanca) se conserva una pintura con las escenas de las apariciones en el que el aspecto de la Virgen y del angelito es muy distinto al del modelo original.

También en este grupo debemos incluir algunos enconchados pertenecientes al Museo de América. Uno de ellos ofrece un vista a los pies de la Virgen del santuario, precedido de un atrio con capillas posas, y la Casa de Ejercicios. A sus lados se observa decoración floral. Otro, que incluye ramas y semillas en relieve, exhibe la basílica en construcción y el resto del espacio lleno de flores. En otro, de pequeñas dimensiones con un ancho marco adornado con pájaros y flores, aparecen en las esquinas flores de las que salen ramas.

49 Clavijo García, Agustín. "Pintura colonial en Málaga y su provincia”..., p. 112. 
En algunos casos el elemento innovador es la forma de la pieza. En el Convento de Trinitarias del Prado de Santa Justa de Sevilla existe un óleo sobre lámina de cobre firmado por Miguel Correa que tiene forma de cruz tetracúspida. Alrededor de la Virgen aparecen símbolos marianos enmarcados en óvalos, y sobre su cabeza el Espíritu Santo. En los brazos de la cruz figuran las escenas de las apariciones numeradas. Los espacios intermedios están decorados con ramilletes de rosas. Encontramos un antecedente en una pintura del mismo autor situada en las Galerías de la Granja de México D.F..

En algunas pinturas la Virgen no es el elemento central. Una titulada "Aparición de la Virgen de Guadalupe a San Francisco Javier" pertenece a una colección particular sevillana. El santo se encuentra en medio de un paisaje junto a niños de color. La Virgen se sitúa en el ángulo superior izquierdo, y Jesús sobre unas nubes, rodeado de angelitos en el derecho. "Las Castas", obra de Luis de Mena que se exhibe en el Museo de América, presenta ocho escenas de las distintas castas novohispanas y bajo ellas una serie de frutas típicas del virreinato. Corona la composición la Virgen de Guadalupe y una imagen de su Basílica. Según María Concepción García Sáiz, esta pintura es compañera de otra muy similar de la que se ignora su paradero. ${ }^{50}$ Este mismo tema figura en un lienzo anónimo conservado en el Museo Nacional del Virreinato de Tepotzotlán (México) y en otro que se encuentra en la Real Academia de la Lengua de Madrid. Un óleo enconchado realizado por José de Arellano en 1709, "Traslado de la imagen y estreno del Santuario de Guadalupe", forma parte de la colección del Duque de Alburquerque, situada en Madrid. Recoge el traslado de la imagen de la Virgen al nuevo santuario por una amplia comitiva presidida por las autoridades, un hecho que tuvo lugar en 1709.51 Además de la Iglesia de los Indios aparecen la Casa de Ejercicios, el cementerio y la Plaza Real. En el ángulo inferior derecho hay una cartela en la que se enumeran personajes y monumentos. Además incluye una inscripción: "Verdadero mapa del sitio en que se benera la milagrosa Yma/gen de Nuestra Señora de Guadalupe...”. Un lienzo que representa a la Santísima Trinidad pintando a la Virgen de Guadalupe pertenece a una colección particular vallisoletana. ${ }^{52} \mathrm{El}$ ayate está sostenido por arcángeles que esperan para transportarla al Santuario que aparece a sus pies. En la esquina inferior se encuentra Juan Diego arrodillado. Dios Padre pinta el lienzo guadalupano, que es sostenido por las otras dos divinas personas. Su mayor atractivo radica en la pareja de angelitos "oficiales" que lo ayudan. Una alegoría similar ha sido recientemente adquirida por el Museo de la Basílica de Guadalupe de México. Una de las variantes más llamativas de la iconografía guadalupana es la referente a la creación del alma de la Virgen, un tema de origen jesuítico. Miguel Cabrera pintó un gran lienzo para el Colegio Máximo de San Pedro y San Pablo en el que "alma de la Virgen" la personificaba una niña rubia que emergía de la Inmaculada. Este esquema dio lugar a un grabado en el que el alma de la niña era sustituida por una Guadalupana. Una de sus versiones pictóricas es la "Virgen de Loreto" de José de Páez que se conserva en el Museo de América de Madrid. En la parte superior se encuentra la Virgen de Loreto con el niño en brazos, y a sus pies una réplica de la Santa Casa de Loreto flanqueada por el arcángel San Gabriel y el Ángel de la Guarda. El resto del espacio está repleto de santos: San Pedro, San Joaquín, San José, San Francisco Javier, San Antonio de Padua, Santa Catalina de Alejandría, Santa Rosalía... La composición se inspira en un grabado de los hermanos Klauber, y tiene un trasfondo crítico ante la expulsión de los jesuitas por Carlos III. ${ }^{53}$

\footnotetext{
50 GARCía SÁrz, Ma Concepción. La pintura colonial en el Museo de América. La escuela mexicana. Madrid, 1980, p. 84 .

51 Berchez, Joaquín. "Catálogo. Entre el documento y el género artístico", Los siglos de oro en los virreinatos de América. 1550-1700. Madrid, 1999-2000, pp. 150-152.

52 Cuadriello, Jaime. Catálogo de la exposición El Divino Pintor..., p. 175.

53 Mateo Gómez, Isabel. "Dos alegorías mexicanas de exaltación de la Compañía de Jesús tras la expulsión de la orden por Carlos III”, IV Jornadas de arte. El arte en tiempos de Carlos III. Madrid, 1989, pp. 377-380.
} 
Estas son algunas de las muestras más representativas de iconografía guadalupana situadas en España; la mayoría óleos sobre lienzo del siglo XVIII, anónimos, que contienen las escenas de las apariciones. Aún así están presentes los principales artistas novohispanos y existen composiciones de gran originalidad que atestiguan un contacto estrecho y continuo con la Nueva España a lo largo de todo el periodo virreinal.

PATRICIA BAREA AZCÓN (Universidad de Granada)

\footnotetext{
* El presente estudio es un avance de algunos datos reunidos en mi tesis doctoral, Vega y Verdugo, Peña de Toro y la introducción del Barroco en Compostela, que será defendida en breve.

${ }^{1}$ Cfr. Fernández Gasalla, L., "El arquitecto José de la Peña de Toro (1614-1676)”, Compostellanum, volumen LI, números 3-4, 2007, p. 325

2 Para lo que aquí concierne, véanse, Bonet Correa, A., La arquitectura en Galicia durante el siglo XVII, Madrid, 1984, pp. 292-309; Chamoso Lamas, M., "La fachada del Obradoiro de la Catedral de Santiago", Archivo Español del Arte y Arqueología, t. XII, 1936, pp. 223-224; Ídem, "El Pórtico Real de la Quintana de la catedral de Santiago", Cuadernos de Estudios Gallegos, t. I, 1944, pp. 45-53; López Ferreiro, A., Historia de la Santa A.M. Iglesia de Santiago, t. IX, Santiago, 1907, p. 294; Pérez Costanti, P., Diccionario de artistas que florecieron en Galicia durante los siglos XVI y XVII, Santiago, 1930, pp. 423-425; Rodríguez G. de Ceballos, A., "Juan Moreno y la arquitectura del protobarroco en Salamanca", Archivo Español del Arte y Arqueología, 1976, pp. 247-271; "Intercambios artísticos entre Galicia y Salamanca”, VI Congreso Español de Historia del Arte. Los caminos y el arte. II, Santiago, 1989, pp. 247-360; Ídem, Estudios del Barroco Salmantino. El Colegio Real de la Compañía de Jesús (1617-1779), Salamanca, 1985, p. 56
} 